\title{
Adjectives co-occurring with the illative form of the MA-infinitive in Finnish and Estonian
}

\author{
PETRA HEBEDOVÁ \\ Masaryk University
}

\begin{abstract}
In both Finnish and Estonian, the illative form of the MA-infinitive/supine can be used at the end of a predicative clause, as in the Finnish olimme hitaita oppimaan ('we were slow to learn') or the Estonian olen küps seda aktsepteerima ('I am ready/ ripe to accept it'). In these sentences, a characteristic expressed by an adjective is attributed to the subject of the sentence, with the scope of the characteristic related to a single activity marked by the illative form of the MA-infinitive/supine. In this paper I will present data to describe this type of construction in both languages and will analyze it as a constructional schema in terms of cognitive grammar (Langacker 2000,2008). My analysis will concentrate on the adjectival component of the schema with the help of examples from Estonian and Finnish corpora.
\end{abstract}

Keywords: illative, MA-infinitive, supine, cognitive grammar, constructional schema, adjective, antonymy 


\section{Constructions with an adjective and an MA-infinitive/ supine $^{1}$ in the illative, according to the literature}

We can find descriptions of the aforementioned construction (ADJEC-

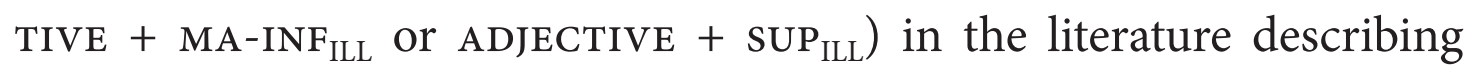
both languages. According to the comprehensive grammar of Finnish Iso suomen kielioppi (ISK 2004: $\$ 620, \S 623, \S 508$ ), a Finnish adverbial clause with an MA-infinitive in illative as its head co-occurs with adjectives expressing ability, suitability, willingness or inclination (example 1). The adjective can be modified by an expression of sufficiency or superfluity such as tarpeeksi 'enough' or liian 'too' (example 2). The adjective is in the syntactic role of a predicate adjective (when it is in the nominative or partitive case, as in examples (1) and (2)) or a predicative adverbial (in the translative, essive or ablative case, example 3 ). The adjective can also be a modifier in a noun phrase (example 4; ISK 2004: $\$ 508$ ).

(1) Siili-t

ovat

arko-j-a ja

hedgehog-NOM.PL be.3PL

shy-PL-PTV and

herkk-i-ä

stressaantu-ma-an.

(Kielipankki, Aamulehti)

sensitive-PL-PTV become.stressed-MAINF-ILL

'Hedgehogs are shy and easily stressed.'

(2)

...ei mikään muuri ole kyllin
NEG.3SG no wall be.CNG enough
korkea estä-mä-än $\quad$ rakkaut-ta (Intercorp, Sinuhe egyptiläinen)
high block-MAINF-ILL love-PTV
‘...no wall can be high enough to stop love'

The terms MA-infinitive and supine have been chosen according to the prevailing traditions in the respective languages. The infinitival form under consideration can be also referred to as the 3rd infinitive in Finnish, and the ma-infinitive in Estonian. For more discussion concerning the infinitives in Finnish and Estonian see, for example, Leino 2003: 99-111 and Tamm 2011: 853-865. It would have been possible to refer to the infinitival forms in both languages using the same term; the use of different terms may nevertheless be helpful in distinguishing which of the two languages is currently spoken of. 
(3) Kotitaloude-t näyttä-vät muutenkin halukka-i-lta household-NOM.PL appear-3PL anyway willing-PL-ABL lisäämään velkaantumis-ta-an. (Kielipankki) add-MAINF-ILL indebtedness-PTV-POS3

'Households seem to be willing to add to their debts anyway'.

(4) Hän on sopiva henkilö johta-ma-an yritys-tä.

s/he be.3sg suitable person lead-MAINF-ILL company-PTV 'S/he is a suitable person to lead the company.'

In the comprehensive grammar of Estonian Eesti keele grammatika (EKG 1993: 254-255, 73), the ability to co-occur with a phrase headed by an illative supine is mentioned for Estonian adjectives expressing suitability (such as kõlblik 'suitable, fit for', kohane 'proper', sobiv 'suitable', sobilik 'proper, suitable', paslik 'fitting', paras 'ideal', example 5) and adjectives that characterize the activity expressed by the supine, or the agent behind it (such as abitu 'helpless', kiire 'quick', kitsi 'mean', raske 'difficult', usin 'diligent, varmas 'prompt', example 6). The second group also includes a handful of nouns (meister 'champion, expert', mees 'man', spetsialist 'specialist', example 7). For adjectives expressing suitability, the phrase headed by the supine is said to be a local adverbial (kohamäärus), but as for adjectives characterizing the activity or agent, the supine is described as an adverbial complement (sõltuvusmäärus).

(5) ...kas inimene on whether person be.3sG riigi asju state.GEN.SG issue.PTV.PL '...whether someone is suitable or not to deal with the state issues!'

(6) Ahv on kiire kaos-t loo-ma. monkey be.3SG quick chaos-PTV create-SUP-ILL 'The monkey is fast to create chaos.'

(7) $\mathrm{Ta}$ on meister anekdoote rääki-ma. s/he be.3sg champion joke.PTV.PL tell-sup.ILL '(S)he's really good at telling jokes.' kõlblik või mitte suitable or not aja-ma! (Tasakaalus korpus) arrange-SUP.ILL
(Tasakaalus korpus)

(EKG 1993) 
In all three examples (5-7), an object of the supine verb (riigi asju, kaost, anekdoote) comes between the adjective and the supine form (whereas in Finnish examples (3) and (4), the object of the infinitive comes after the infinitive).

Tauli (1983: 221) also discusses this construction, mentioning combinations of an adjective (such as esimene 'first', helde 'lavish', kärmas 'quick', hoolas 'diligent', viimane 'last', võimetu 'incapable' etc.) or an adverb (nõus 'in agreement, being in for', valmis 'ready') with the supine, such as oppima ta on hoolas 'he is diligent in his studies'. He states that the supine expresses "the action in which the meaning expressed by AdjN/Adv appears". Tauli also gives a list of possible variations of word order within the construction.

\section{Constructional schemas}

A constructional schema is an assembly of symbolic units that can be abstracted from specific constructions occurring in a language (Langacker 2008: 167-170, Langacker 2000: 21, 32-33, 53). The construction that is the focus of this paper could be preliminarily described as the constructional schema $\left[[\mathrm{ADJ} / \ldots]\left[\right.\right.$ VERB-MAINF $\left.\left.{ }_{\mathrm{ILL}} / \ldots \mathrm{mAAn}\right]\right]$ in Finnish, and $\left[[\mathrm{ADJ} / \ldots]\left[\mathrm{VERB}^{\mathrm{SUP}} \mathrm{ILL} / \ldots \mathrm{ma}\right]\right]$ in Estonian. In the case of the Finnish, [ADJ/...] is an abstraction of examples such as [NOPEA/nopea], [HYv̈̈/ hyvä] or [VALMIs/valmis]. The semantic pole of the schematic symbolic unit $[\mathrm{ADJ} / . .$.$] can be specified as \mathrm{ADJ}$ (= an adjective), while the phonological pole is left wholly unspecified (therefore '...'), because adjectives do not share common phonological features in Finnish. Square brackets are used to indicate that the symbolic assembly is an established unit. Similarly [VERB-MAINF ILL $/ . . . \mathrm{mAAn}$ ] is an abstraction of symbolic units such as [OPPIA-MAINF ${ }_{\text {ILL }} /$ oppimaan], [PUHUA-MAINF ILL $_{\text {puhumaan], }}$,

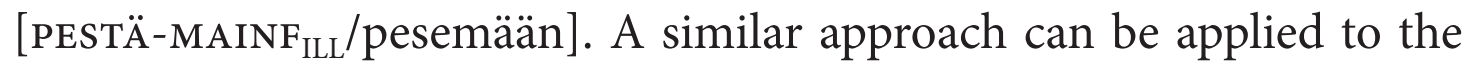
Estonian schema.

Alternatively, we could also describe the illative form of the MAinfinitive/supine by specifying each morpheme in the form, e.g. the 
verbal stem, the infinitival morpheme (phonologically - $m A$ - in Finnish, $-m a$ in Estonian) and the illative case (phonologically - $V n$ in Finnish, $-\varnothing$ in Estonian ${ }^{2}$ ), as well as the hierarchy of these constituents. The infinitival part of the schema would then be $[[\mathrm{VERB} / \ldots][\mathrm{MAINF} /-\mathrm{mA}-][\mathrm{ILL} /-$ An] ] in Finnish, and [[VERB/...][sup/-ma] [ILL/-ø]] in Estonian.

We could also expand the description of the constructional schema to include the finite verb of the clause, which is in most cases the verb olla/olema 'to be. For Estonian the schematic representation is then

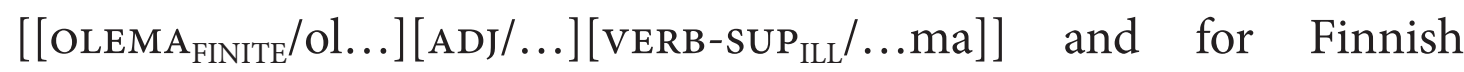
$\left[\left[\text { OLLA }_{\mathrm{FINITE}} / \mathrm{ol} . . .\right][\mathrm{ADJ} / \ldots]\left[\mathrm{VERB}-\mathrm{MAINF}_{\mathrm{ILL}} / \ldots \text { mAAn }\right]\right]^{3}$. In both languages the finite verb and the adjective agree in number. However, these schemas containing olla/olema would not encompass all possible examples, namely some sentences with the adjective in a case other than the nominative, e.g. in Finnish the translative, essive or ablative (example 3). In order to include such examples and other similar sentences, we would have to specify this part of the constructional schema only as a finite

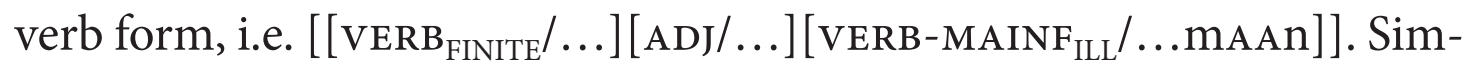
ilarly in Estonian, where the adjective can be in the translative or the essive with a verb other than olema 'to be', the more abstract schema encompassing these examples would then be $\left[\left[\operatorname{VERB}_{\mathrm{FINITE}} / \ldots\right][\mathrm{ADJ} / . .]\right.$. [VERB-SUP $\left.{ }_{\text {ILL }} / . . . \mathrm{ma}\right]$ ].

We could also think of more specific constructional schemas,

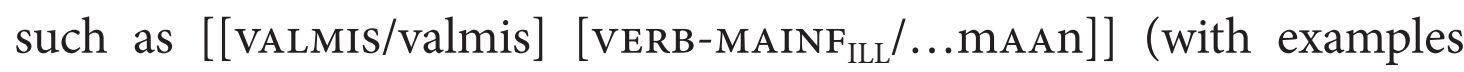
such as valmis kertomaan, valmis olemaan) or [[VALMIS-Ess/valmiina]

2 In EKG I (1995: 65) the morphological form in question (the illative form of supine) is said to be historically in illative. This is presumably due to the fact that in contrast to other case forms of supine (inessive, elative, translative and abessive) there is no overt ending. But it is nevertheless possible to analyze the form as an illative form with a zero morpheme ending -ø. Other sources (EKG II 1993: 251; Viitso \& Erelt 2007: 64) speak of an illative form of supine without the qualification "historical".

3 The fact that the order of the components is not necessarily as indicated and that other words can come between the mentioned components is not crucial at this point. The components (the finite verb, the adjective, the illative form of infinitive/supine) are in any case in syntagmatic relation to one another. 
[VERB-MAINF ${ }_{\text {ILL }} / \ldots$ mAAn]] (with examples such as valmiina kertomaan, valmiina olemaan) in Finnish or [[vốIMELINE/võimeline] [VERB$\left.\operatorname{suP}_{\mathrm{ILL}} / \ldots \mathrm{ma}\right]$ ] (with examples such as võimeline pakkuma, võimeline sõnastama) in Estonian, where the adjectival component is specific. These more specific schemas are schematic with respect to specific constructions such as valmis kertomaan, valmiina olemaan, võimeline sõnastama. On the other hand, they are instantiations of the more abstract constructional schemas mentioned previously.

Such constructional schemas represent a part of the grammar of a language, an established pattern that a speaker may rely on in order to use or judge expressions analogous to it. Once established (having the status of a unit in the respective language), the constructional schema can serve as a template in the categorization of other similar expressions (Langacker 1987: 66; Langacker 2000: 5). However, not all of the examples that we can think of, use, or understand are necessarily coherent with the constructional schema in every detail. It is possible to depart from some of the specifications and form expressions that would be only partly categorized by the schema. Such an expression would represent an extension with respect to the schema as well as with respect to its prototypical, unproblematic examples (Langacker 1987: 68-71, 371-373). For example, we can think of the construction with a noun phrase in combination with the illative form of the MA-infinitive/supine (such as hän on sopiva henkilö johtamaan yritystä, ta on meister anekdoote rä̈kima, examples 4 and 7), which apparently has a meaning similar to the adjectival construction, as an extension or syntactic variation on the schema (rather than the other way around, as the adjectival variant seems to be much more common). In Estonian we can also think of a variant with an adverb instead of an adjective (nõus or valmis, such as olin nõus seda tegema 'I consented to do it', Tauli 1983: 221)4. One can also imagine that some adjectives appear in this construction frequently

\footnotetext{
4 The difference between the adjectival and the adverbial variant is not radical: an adverb is said to have a relational predicate as its trajector (in ta on nõus elaborated by ta on), whereas an adjective typically has a thing as its trajector (in ta on kiire elabora-
} 
and that constructions such as valmis + ...maAn ('ready to ...') in Finnish or voimeline + ...ma ('able to ...') in Estonian are themselves well established units, but that it is possible to stretch the boundaries of what is ordinary and use the schematic template $\mathrm{ADJ}+\mathrm{MA}-\mathrm{INF}_{\mathrm{ILL}}$ or $\mathrm{ADJ}+$ SUP $_{\text {ILL }}$ in order to form novel expressions, for example with an adjective that does not usually or frequently appear in this context.

The constructional schema, as was already mentioned, consists of symbolic units (at least the finite verb and its personal ending, the adjective and the number and the case it takes, the verb in combination with the infinitival morpheme and the illative morpheme), and the constructional schema has itself a symbolic character (we can say that the schema has a form and a meaning as a whole). In order to characterize it precisely we would need to specify all of its formal, phonological properties (how these are manifested and combined, as was sketched earlier), as well as to provide the semantic characteristics of its components and how these combine.

In very general terms, the semantic characteristics of the constructional schema can be described in the following way. In the Finnish sentence hän on nopea oppimaan 's/he is quick to learn', the adjective nopea 'quick' is a relational predicate that specifies the relation of its trajector (elaborated by hän 's/he') and a particular area on the scale of speed (Langacker 2008: 116). The copula on 'is' lends its processual character to this relationship (Langacker 2008: 396), so that the relation (hän on nopea 'he/she is quick') is conceived as ongoing, extended through time. The MA-infinitive in the illative further specifies as to what activity this characteristic pertains ${ }^{5}$. The verbal stem specifies the activity (in this

ted by the subject $t a$, the copula on lends its processual character to the relationship) (Langacker 2008: 115-116; Langacker 1987: 242).

5 The MA-infinitive in illative can be further analyzed as specifying the active zone of the subject (in this case hän) in its relationship with the scale of speed (specified by nopea), accordingly to Langacker (1995: 25-30, 39-40). According to Langacker (1995) it is the process expressed by the infinitive that is directly engaged in the relationship with the specification given by the adjective and the subject's relation to the characte- 
case oppi- 'learn'). The primary semantic import of the infinitival morpheme - $m A$ - lies in imposing a summary scanning on the verbal process (Langacker 2008: 117-120). The illative is again a relational predicate; its landmark is elaborated by the nominalized verb oppima-, and its trajector is elaborated by the now processual relation hän on nopea. The illative profiles a complex atemporal relationship extending from separation to inclusion (Leino 1999: 178-181).

The question may arise: why is it the illative that is used in the construction? Why is it the dynamic directional case and not, for example, the inessive (cf. the Finnish expression hän on hyvä matematiikassa 'he/ she is good at math')? Briefly, it seems perfectly possible to connect this use of the illative to other typical uses of the illative form of the MAinfinitive, where someone "enters" an activity, whether in time and space (lähden uimaan 'I'm going swimming'), by beginning the activity ( $r y h$ dyn opiskelemaan 'I begin to study'), learning how to do something (opin uimaan 'I am learning to swim'), or, crucially, by having the ability or will to do something (pystyn jo kävelemään 'I am already able to walk') Such an approach would be consistent with the concept that the semantic pole of the illative is polysemic and the various contexts in which it appears, including those where it is used with the MA-infinitive, are linked together in a polysemic network (see, for example, Leino 1999: 172-206, 220-238; Janda 1993).

In this paper we concentrate mainly on the adjective component of the schema. What adjectives appear in the construction and how frequently? Is it possible to provide a description of the $[\mathrm{ADJ} / . .$.$] component$

ristics given by the adjective is mediated by the process expressed by the infinitive. The infinitive expresses a process of which the subject is the trajector and it is this process along with its most salient participant, e.g. the trajector, which characteristics is being specified. The specification of the active zone of the subject can be also left implicit as in that surgeon is really fast vs. when it comes to suturing, that surgeon is really fast, or in portraits are tough vs. portraits are tough to paint (Langacker 1995: 29-30, 39-40).

6 Concerning the uses of the Estonian supine in illative, see Pajusalu \& Orav 2008: 108-111. 
of the constructional schema? Do Finnish and Estonian differ in this respect? To consider this question, I turned to corpora data for examples of the construction in use.

\section{Examples from corpora}

The possible uses of the construction with an adjective and the illative form of the MA-infinitive/supine were tested in corpora for both languages. The primary objective was to find out what adjectives appear in the construction and how often. The corpora were tested for adjectives found in the literature mentioning the construction, and, in order to find other possible examples of the constructional schema, by searching for an adjective directly followed by the MA-infinitive/supine in the illative.

In both languages, active past participles such as harjunud 'used to' in Estonian, and kiinnostunut 'interested in', innostunut 'enthusiastic' or väsynyt 'tired' in Finnish were not taken into account; also excluded were passive past participles such as sunnitud 'forced' in Estonian. The use of the illative form of the MA-infinitive/supine can be in such cases identical to its use with the respective verbs (harjuma 'get used', kiinnostua 'get interested', innostua 'get enthusiastic', väsyä 'get tired', sundima 'force'), and it would be overly complicated to try to determine in which of the sentences the participle is used adjectively to a sufficient degree. On the other hand, adjectives that are morphologically present participles (pädev 'competent' or osav 'good at' in Estonian, riittävä 'sufficient' or kykenevä 'able' in Finnish) were included, as the aforementioned problem does not arise with them.

\subsection{Examples of the Estonian construction with an adjective and an illative supine}

For Estonian, the Balanced Corpus of Estonian (Tasakaalus korpus) ${ }^{7}$ was used, which consists of 15 million words, divided evenly among

$7 \quad$ Accessible from www.keeleveeb.ee. 
journalistic texts, fiction, and scholarly texts. The Balanced Corpus was chosen because different adjectives might be used unevenly in the construction under consideration in different types of texts. The attested adjectives and number of occurrences in the construction are summed up in Table 1.

TABLE 1. Adjectives used with the illative form of the supine in Estonian (Tasakaalus korpus)

\begin{tabular}{|c|c|}
\hline võimeline 'capable, ablè & 777 \\
\hline suuteline 'capable, able' & 248 \\
\hline varmas 'prompt, firm' & 42 \\
\hline võimetu 'incapable, unable' & 37 \\
\hline pädev 'competent' & 36 \\
\hline vaba 'free' & 25 \\
\hline kerge 'easy, light' & 23 \\
\hline visa 'persistent' & 16 \\
\hline kiire 'quick, swift' & 15 \\
\hline küps 'ripe', kitsi 'mean' & 10 \\
\hline agar 'ardent, enthusiastic' & 7 \\
\hline osav 'good at', aldis 'prone to' & 6 \\
\hline lahke 'kind, benevolent', sobiv 'suitable' & 5 \\
\hline raske 'hard, heavy, difficult', usin 'diligent', laisk 'lazy', & 4 \\
\hline kärme 'brisk', kange 'good at, strong' & 3 \\
\hline $\begin{array}{l}\text { aeglane 'slow', tõrges 'wayward', virk 'diligent', paras 'ideal', sobilik } \\
\text { 'proper' }\end{array}$ & 2 \\
\hline $\begin{array}{l}\text { helde 'generous', prii 'free', vihane 'angry', äge 'fierce, vehement', väle } \\
\text { 'agile, brisk', kaval 'cunning,' loid 'vigoursless', nobe 'quick, terane } \\
\text { 'sharp', kohane 'proper', abitu 'helpless', tugev 'strong, sturdy', aktiivne } \\
\text { 'active', kangekaelne 'headstrong', kõlblik 'suitable, fit for' }\end{array}$ & 1 \\
\hline
\end{tabular}

$8 \quad$ Translations into English are only representative - in context the translation may differ. 
To compile the data, the corpus was searched for the co-occurrence of the verb olema 'to be', an adjective (as a lemma), and an illative form of the supine. The results were then manually reviewed for any problematic cases. The method allowed for any number of word forms between the forms that were searched for (cf. eestlanna oli lõpuks peaaegu vaba oma lemmiklinna tänavate lummust sisse ahmima 'the Estonian lady was finally almost free to indulge in the charm of the streets in her favourite city'), and the word order was flexible (...esteete silmama on nad eriliselt terased lit. "to spot aesthetes they are particularly keen", ... mida ma Soomes käies varmas olin kasutama lit. "... which I, when visiting Finland, eager was to use"), though these variations were rare. Occurrences with multiple supine forms, such as olen võimeline püsti tõusma ja kõndima ('I am able to stand up and walk'), were counted as one. The adjective can also appear in comparative or superlative forms (...siis oli tuli veelgi kergem tulema '... fire was then even more likely to come', ...oli taas väikemees kõige varmam vastama, '... and again was the small man quickest to reply'); these forms were searched for separately (adjective in comparative form + supine in illative).

Though Estonian grammars do not mention it specifically, there is a variation on the constructional schema in which the adjective is in the translative or the essive (...keda peeti võimeliseks TRANSL $_{\text {tegutsema kirja- }}$ nikuna, '... who was considered capable of working as a writer', ma kuulasin ta sõnu kummaliselt võimetuna ${ }_{\mathrm{ESS}}$ midagi ütlema, 'I listened to his/ her words curiously unable to say anything'). This variation is similar to the Finnish case, in which the adjective can be in the translative, essive or ablative. In order to find examples such as these, the search was done for an adjective from Table 1 above in the appropriate case (translative, essive) in combination with an illative form of the supine. The search resulted in 9 examples with the translative and 5 with the essive; only the adjectives võimeline, võimetu, sobilik and sobiv appeared in this context.

Of the adjectives that occurred most frequently, the majority of the sentences with võimeline appeared in scholarly texts, though the other two text types were also represented. Also suuteline most often occurred 
in scholarly texts. The most common adjectives võimeline and suuteline, alongside with võimetu or vaba and prii can be seen as expressions of modality (examples 8-11), as opposed to those ascribing a certain inclination or characteristic to a subject, as in examples (12-14).

(8) Ütle-si-n, et ole-n võimeline teis-te say-PST-1SG that be-1SG able other-GEN.PL inimes-te mõtte-id luge-ma. person-GEN.PL thought-PTV.PL read-SUP.ILL 'I said I was able to read other people's minds.'

(9) $\mathrm{Ma}$ ei usu, et ole-n suuteline I NEG believe.CNG that be-1SG able nähtu-t adekvaatselt kirjelda-ma. see.IPS.PTCP-PTV adequately describe-SUP.ILL 'I'm not sure I'm able to describe adequately what I've seen.'

(10) mulje, mi-da me ole-me võimetu-d defineeri-ma. impression which-PTV we be-1PL unable-NOM.PL define-sUP.ILL 'an impression, which we are unable to define'

(11)..siis ma ole-ksi-n vaba mine-ma ja then I be-COND-1SG free go-SUP.ILL and ole-ma kus tahes. be-SUP.ILL where _ever '...then I would be free to go and to be wherever'

(12) Oh küll te ole-te äge kritiseeri-ma! oh EMP you.PL be-2PL fierce criticize-SUP.ILL 'Oh, but you are fierce in criticism!'

(13) Komöödia on iseäranis aldis reageeri-ma comedy be. 3 particularly prone react-suP.ILL aktuaalse-te-le kollisiooni-de-le ühiskonna elu-s. current-PL-ALL collision-PL-ALL society.GEN.SG life-INE 'Comedy is especially prone to react to current collisions in societal life.' 
(14) Alkohol anna-b petliku õnne-tunde alcohol give-3sG deceptive.GEN.SG joy.GEN.sG-feeling.GEN.SG ja on kaval ahvatle-ma. and be. 3 cunning entice-sup.ILL

'Alcohol gives you a deceptive feeling of joy and is cunning at enticing.'

Also of note in the material collected from the Balanced Corpus of Estonian are sentences with inanimate subjects that express the likelihood with which something happens or the manner in which things are experienced to happen (examples 15-20). In these cases, the supine verb in the illative is an intransitive verb. These constructions typically involved the adjectives kerge 'easy, light', raske 'difficult, heavy', visa 'steadfast, persistent' or kiire 'quick', but appeared also with adjectives that otherwise co-occurred mostly with animate subjects (varmas 'prompt').

(15) Aga jama on kerge juhtu-ma.

but mess be.3 easy happen-sup.ILL

'A mess can occur easily.'

(16) ...kuid sündmus-te tagajärjel tekki-nud but event-GEN.PL in.consequence arise-PST.PCTP haava-d on raske-d parane-ma. wound-NOM.PL be.3 difficult-NOM.PL heal-sup.ILL

'But the wounds that occurred as a result of the events will heal with difficulty.'

(17) Sügis on kiire tule-ma. autumn be.3 quick come-SUP.ILL 'Autumn is quick to come.'

(18) Aasta-d on kärme-d/vihase-d kulu-ma. year-NOM.PL be.3 brisk-NOM.PL/fierce-NOM.PL run.out-SUP.ILL 'Years are quick to pass.'

(19) Vana-d harjumuse-d on eriti Kesk-Euroopa-s old-NOM.PL habit-NOM.PL be.3 especially Central.Europe-INE visa-d kadu-ma. persistent-NOM.PL disappear-SUP.ILL 'Old habits are hard to shake, especially in Central Europe.' 
(20) ...on haiguse-d ja viiruse-d se-l aasta-l be.3 disease-NOM.PL and virus-NOM.PL this-ADE year-ADE eriti varma-d tule-ma. especially sure-NOM.PL come-SUP.ILL '...diseases and viruses are especially eager to come this year'

The corpus was also searched for the syntactical variation of the construction mentioned above and in EKG (1993: 254-255), in which the place of the adjective is taken by a noun such as meister 'champion' or mees 'man'. There were five sentences with meister in the corpus (example 21); mees was used only accompanied by a modifier such as õige 'right', paras 'the best, ideal', kovva 'tough', andekas 'talented' (example 22). These examples were not included in the table above.

(21)

$\begin{array}{llll}\text { Luuleta-ma } & \text { ole-te } & \text { te } & \text { meistri-d. } \\ \text { compose.poetry-SUP.ILL } & \text { be-2PL } & \text { you.PL } & \text { champion-NOM.PL } \\ \text { 'You're very good at telling tales.' } & & \end{array}$

(22) Mina ole-n just õige mees

I be-1SG just right man

talle nende-st rääki-ma.

s/he.ALL they-ELA tell-sup.ILL

'I'm just the right man to tell him/her about them.'

As for the variant with an adverbial expression (valmis 'ready', nõus 'in agreement, being in for') instead of an adjective, there were 630 occurrences with nõus (if included in Table 1, nõus would be second most common, after võimeline), and 247 sentences in which valmis co-occurred with the supine in the illative (valmis would come after suuteline in Table 1). Valmis 'ready' is, unlike in Finnish, indeclinable in Estonian (example 23), and is therefore considered here an adverb along with nõus (Tauli 1983: 221).

(23) Me ole-me kohe valmis reageeri-ma.
we be-1PL immediately ready react-SUP.ILL
'We are ready to react immediately.' 


\subsection{Examples of the Finnish construction with an adjective and an illative MA-infinitive}

Finnish adjectives co-occurring with the MA-infinitive in the illative were searched for in two different corpora: the Kielipankki corpus and InterCorp. In the Kielipankki corpus, ${ }^{9}$ the search was done in journalistic texts (two years' volumes of the newspaper Aamulehti, 1995 and $1999^{10}$ ) with use of the Lemmie search tool. In order to encompass different text types, the construction was also searched for in Finnish texts available in the parallel corpus InterCorp, part of the Czech National corpus ${ }^{11}$. This corpus includes EU legal texts (the Acquis Communautaire corpus), the proceedings of the European Parliament from 2007 to 2011 (the Europarl corpus), film subtitles, and fiction and nonfiction (written originally in Finnish or translated into Finnish ${ }^{12}$ ). An area of concern with this second corpus is that it mostly consists of texts translated into Finnish from other languages, so the influence of patterns typical for source languages is possible. The InterCorp subcorpus was approximately twice as large as the Kielipankki subcorpus.

The search method was slightly different from that used in the case of Estonian constructions. The search was done for a combination of an adjective (as a lemma) followed by the MA-infinitive (3rd infinitive) in the illative ${ }^{13}$. The search results include sentences in which the MAinfinitive directly follows the adjective or where there are one or two positions between them. This means that there may be more such constructions, with more than two positions between the adjective and the infinitive or where these are in reversed order, which are not included in

\footnotetext{
9 https://sui.csc.fi

10 The subcorpus consists of 20447243 tokens.

11 http://ucnk.ff.cuni.cz/intercorp/?lang=en, http://www.korpus.cz

12 The subcorpus has 59684090 positions.

13 The coding of the Finnish part of the InterCorp: Fárová, L.; Vavřín, M. 2015. Korpus InterCorp - finština, verze 8 z 4. 6. 2015. Praha: Ústav Českého národního korpusu FF UK.
} 
the search results. The results should, however, give a good overview of the adjectives typically used in the construction and the frequency with which they appear. Results were again reviewed manually, and in the case of very frequent adjectives such as valmis, only cursorily. Adjectives found in the two corpora and the number of occurrences are summed up in Table 2. (If the adjective was found in both corpora, the translation is given in the left column, so that adjectives with translation on the right were found only in InterCorp.)

TABLE 2. Adjectives used with the illative form of the MA-infinitive in Finnish (Kielipankki, InterCorp)

\begin{tabular}{|l|r|}
\hline Journalistic texts (Kielipankki) & 2263 \\
\hline valmis 'ready' & 259 \\
\hline halukas 'willing' & 95 \\
\hline velvollinen 'obligated' & 74 \\
\hline haluton 'reluctant' & 61 \\
\hline innokas 'enthusiastic' & 52 \\
\hline kova 'keen' & 36 \\
\hline hyvä 'good' & 34 \\
\hline vapaa 'free' & 28 \\
\hline taipuvainen 'inclined', herkkä 'tender' & 21 \\
\hline kyvytön 'inept' & 20 \\
\hline esteellinen 'disqualified' & 18 \\
\hline kypsä 'ripe' & 13 \\
\hline kärkäs 'anxious' & 12 \\
\hline kykenevä 'able' & 11 \\
\hline laiska 'lazy' & 10 \\
\hline arka 'shy, timid', vanha 'old' & 9 \\
\hline hanakka 'eager', altis 'prone to' & 7 \\
\hline utelias 'curious', hidas 'slow', jäävi 'disqualified, challengeable' & 6 \\
\hline heikko 'weak', ujo 'shy' & 5 \\
\hline kelvollinen 'fit for, eligible', nopea 'swift', kyvykäs 'capable, apt' \\
\hline
\end{tabular}




\begin{tabular}{|l|c|}
\hline etevä 'excellent' & 4 \\
\hline suostuvainen 'amenable', sairas 'ill', nuori 'young' & 3 \\
\hline $\begin{array}{l}\text { aulis 'willing', kelpoinen 'fit for, suited', nöyrä 'meek', avoin 'open' } \\
\begin{array}{l}\text { pätevä 'qualified', fiksu 'clever', tarkka 'precise', kiireinen 'hasty', } \\
\text { toimivaltainen 'competent' }\end{array}\end{array}$ & 2 \\
\hline
\end{tabular}

\begin{tabular}{|c|c|c|c|}
\hline \multicolumn{4}{|c|}{ Legal texts, EuroParl, subtitles and fiction/nonfiction (InterCorp) ${ }^{14}$} \\
\hline valmis & 4445 & taitava 'skilled', vanha & 34 \\
\hline velvollinen & 656 & hidas & 25 \\
\hline halukas & 582 & kypsä & 19 \\
\hline hyvä & 313 & kelpoinen, sopiva 'suitable' & 18 \\
\hline toimivaltainen & 231 & kelvollinen, heikko & 17 \\
\hline vapaa & 173 & kärkäs & 15 \\
\hline haluton & 168 & kiireinen & 10 \\
\hline riittävä 'sufficient' & 167 & surkea 'lousy' & 13 \\
\hline kykenevä & 136 & altis, tyhmä 'stupid' & 12 \\
\hline innokas & 135 & kyvykäs, herkkä & 9 \\
\hline pätevä & 116 & avoin & 8 \\
\hline taipuvainen & 81 & fiksu & 7 \\
\hline kyvytön & 68 & tarkka & 6 \\
\hline utelias & 67 & arka, laiska, hullu 'mad' & 5 \\
\hline kova & 66 & \multirow{2}{*}{$\begin{array}{l}\text { lahjakas 'talented', etevä, } \\
\text { älykäs 'intelligent' }\end{array}$} & \multirow{2}{*}{4} \\
\hline nuori & 56 & & \\
\hline huono 'bad, poor' & 52 & \multirow{3}{*}{$\begin{array}{l}\text { ujo, suostuvainen, loistava } \\
\text { 'excellent', aulis, sairas, korkea } \\
\text { 'high', hanakka }\end{array}$} & \multirow{3}{*}{3} \\
\hline vahva 'strong' & 48 & & \\
\hline nopea & 42 & & \\
\hline & & $\ldots{ }^{15}$ & \\
\hline
\end{tabular}

The two corpora are of different size and consist of different text types (the InterCorp corpus consists of mixed text types, as was the case with the Balanced Corpus of Estonian). It is also possible that they were constructed or coded differently. It is therefore not advisable to compare

14 The proportion of subcorpora (in words) is: legal texts 16455 144; EuroParl 10175 256; subtitles 15097 653; fiction and nonfiction 3426226.

15 Adjectives that appeared one or two times in InterCorp are not enumerated. 
the exact number of occurrences between the two corpora, but rather to focus on the range of adjectives that appear in the construction and their relative frequencies. In both corpora, the construction with valmis was decidedly the most frequent. Some differences between the two corpora are due to use of certain constructions in legal text (included in InterCorp). For example, the adjective toimivaltainen 'competent' was used almost exclusively in legal texts, which also provided a considerable share of the occurrences of velvollinen 'obligated', riittävä 'sufficient' and pätevä 'qualified'. On the other hand, the adjectives esteellinen and jäävi 'disqualified, challengeable' which also appear typically in a legal context, were found only in the journalistic texts of the Kielipankki corpus.

In comparison with Estonian, the Finnish corpora offer a wider range of adjectives. This may to some degree be due to the size of the corpora, but there is also another significant reason for this. In Finnish, unlike in Estonian, the construction is used to express whether the subject has or has not (to a sufficient degree) a quality to fulfill some specific purpose or objective (example 2 and examples 24-26). In Estonian, the translative form of the supine or a subordinate clause (et + da-infinitive) would be used in these contexts (for example ta on liiga noor hääletamaks ta on hääletamaks liiga noor ta on liiga noor, et hääletada's/he is too young to vote'; Viitso \& Erelt 2007: 64, 124 ${ }^{16}$ ).

(24) Ole-t liian nuori äänestä-mä-än. be.2SG too young vote-MAINF.ILL (Subtitles) 'You're too young to vote.'

(25) Katso-n, että ole-tte riittävän vahvo-j-a take.the.view-1sG that be-2PL sufficiently strong-PL-PTV salli-ma-an polittise- $n$ moniarvoisuude- $n$. (Europarl) allow-MAINF-ILL political-GEN.SG plurality-GEN.SG 'I think that you are strong enough to allow political plurality.'

16 The translative form of the supine was suggested as an innovation by Johannes Aavik, but was adopted on a larger scale into the standard language only in the 1960s. It is currently used in spoken language as well. (EKG II 1993: 251.) 
(26) ...että käyte-ttävä-t laittee-t ovat

that use-PASS.PTCP.PRS-PL appliance-NOM.PL be.3PL

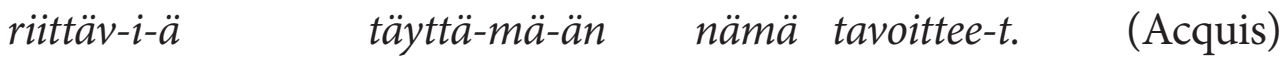
sufficient-PL-PART fulfill-MAINF-ILL these objective-NOM.PL '... that the equipment used is capable of meeting these objectives.' ${ }^{\prime 7}$

Some of the adjectives from the table (especially from the InterCorp column) appear typically or exclusively to express suitability for the purpose or objective that is marked by the illative form of the MA-infinitive. This includes riittävä 'sufficient', nuori 'young', vanha 'old', vahva 'strong', fiksu 'clever', sopiva 'suitable', kypsä 'ripe, mature', heikko 'weak', kiireinen 'hasty', tyhmä 'stupid', tarkka 'precise', älykäs 'intelligent', korkea 'high', sairas 'ill'. This is less common in the material from Kielipankki, but appears there as well, with the adjectives heikko 'weak', nuori 'young', tyhmä 'stupid', fiksu 'clever', sairas 'ill'. The frequent use of such constructions in the InterCorp corpus often seems to be a result of translation from another language (for example, constructions such as olet liian nuori äänestämään / polttamaan / muistamaan / ymmärtämään... 'you are too young to vote/smoke/remember/understand/..., which appeared frequently in the Subtitles subcorpus ${ }^{18}$ ).

In these cases, the adjective is usually preceded by a modifier such as liian 'too', kyllin 'enough', riittävän 'sufficiently', tarpeeksi 'enough', melko 'quite', aika 'rather', while in other cases, the adjectives riittävä 'sufficient' and sopiva 'suitable' bear the sense of suitability already. These modifiers then specify the degree or amount of the quality needed for a specific

17 In the case of examples from the parallel corpus InterCorp, the English versions are taken from the corpus if available. In some cases the English version was the original and the Finnish sentence is translated from it; however, the source language is not necessarily English, and in the case of the Acquis subcorpus the source language is left unspecified.

18 Of the 104 Intercorp occurrences of the modifier liian in combination with nuori/ vanha/fiksu/heikko/tyhmä/sairas, 89.4\% came from texts translated from English; 95.7\% of these translations from English belong to the Subtitles subcorpus. They were translated from source sentences in which the modifier too, or in some cases so, a little or some other similar modifier, was used. 
purpose and therefore are typical in the aforementioned context of expressing suitability.

In some cases, adjectives that otherwise express a subject's inclination to do something, or characteristics that the subject possesses that enable the activity, can also be read as expressing suitability for a purpose or objective (example 25). Some adjectives can very well be used in both contexts (examples 27 and 28). Whereas in Estonian, two different constructions, with the supine in the illative or the translative, distinguish these two meanings, it would be difficult to draw an exact line between Finnish constructions that express inclination, willingness or ability to do something and those that express suitability for that activity.

(27) ...kun huomaa, että suomalaise-t ovat when notice.3SG that Finn-Nom.PL be.3PL laisko-j-a pese-mä-än autoja-an. (Aamulehti) lazy-PL-PTV wash-MAINF-ILL car.PL.PTV-POS3

'... when you notice that Finns are lazy about washing their cars.'

(28) Ellen ol-i liian laiska lähte-mä-än

Ellen be-PST.3Sg too lazy go-MAINF-ILL

lenki-lle kanssa-ni.

(Subtitles)

jog-ALL with-POS1SG

'Ellen was too lazy to jog with me.'

In Finnish the adjective can be in the nominative, partitive, essive, translative or ablative case (examples 3, 29, 30; ISK 2004: $\$ 620$ ). The essive case is quite typical with valmis 'ready'. Adjectives in the comparative were also quite frequent in the material (example 31). Sentences with a finite verb other than olla 'to be' (examples 3, 29, 30) are more complex, in that the finite verb brings more than its prosessual character to the relation between the subject and the adjective (as opposed to hän on nopea oppimaan 's/he is quick to learn', which was considered earlier). In addition, the semantic pole of the essive, translative or ablative plays a role in the construction. The constructional schema with olla 'to be' could be seen as prototypical (as it is less complex and also more frequent), and examples such as (3), (29), and (30) can then be seen as a 
variation on the simpler schema. A similar approach can be adopted in Estonian, where the examples with the adjective in the translative or the essive formed only a small part of the collected material. These examples have been included in the data presented here (i.e. in Tables 1 and 2), though admittedly these variants of the proposed constructional schema would be worth more detailed analysis.

(29) Hän istu-u matkalauku-n päällä valmii-na s/he sit-3SG suitcase-GEN.SG on ready-ESs lähte-mä-än Brysseli-n komennukse-lle. go-MAINF-ILL Brussels-GEN.SG assignment-ALL

(Aamulehti) 'He is sitting on his suitcase, ready to leave for his assignment in Brussels.'

(30) Yksi asukka-i-sta ilmoittautu-i halukkaa-ksi one resident-PL-ELA sign.in-PST.3SG willing-TRANSL hoita-ma-an komposte-j-a.

(Aamulehti) take.care.of-MAINF-ILL compost-PL-PTV

'One of the residents volunteered to take care of the compost.'

(31) Naise-t ovat ol-lee-t innokkaa-mp-i-a woman-NOM.PL be.3PL be-PST.PTCP-NOM.PL enthusiastic-COMP-PL-PTV äänestä-mä-än kuin miehe-t. (Aamulehti) vote-MAINF-ILL than man-NOM.PL 'Women have been more eager to vote than men.'

In Finnish we can also find a syntactical variation of the schema where a noun phrase takes the place of the adjective. In all of the examples from Finnish corpora, the noun co-occurs with an adjectival modifier (one of the adjectives from the table above; see also ISK 2004: $\$ 508$ ), unlike in Estonian, where meister 'champion, expert' is used without an adjective modifier.

(32) Hän ol-i jo tuolloin kova poika s/he be-Pst.3sg already then tough boy puhu-ma-an. (Aamulehti) speak-MAINF-ILL

'He was already then a very keen speaker. / Already then, he talked a great deal.' 
(33) Hän on luonnollisesti=kin sopiva henkilö

s/he be.3sG naturally=EMP suitable person

käsittele-mä-än nais-ten suojelu-a. (Europarl)

deal.with-MAINF-ILL woman-GEN.PL protection-PTV

'... who, of course, is well disposed to protect women ...'

(34) Tiedän, että sinu-lla on hyvä pää

know-1SG that you.SG-ADE be.3SG good head

keksi-mä-än taktiiko-i-ta. ${ }^{19}$

(Subtitles)

invent-MAINF-ILL tactics-PL-PTV

'I know you have a good head for tactics.'

Again the sense of suitability for a purpose or objective can be detected in example 33. The ability to express suitability thus seems to be stronger in the Finnish construction ADJ + MA-INF ${ }_{I L L}$ than in the Estonian construction $A D J+S_{\text {ILL }}$, though one could not say that it is totally absent in Estonian. The construction can be used with Estonian adjectives such as sobiv, kohane, sobilik, paras, kõlblik (example 5), though these were not very frequent in our material. In EKG (1993: 254-255), these adjectives expressing suitability are treated separately from the combination of the illative form of the supine with adjectives such as varmas, kiire, and kerge. This separate treatment could be also motivated by the existence of a separate construction ADJ $+\mathrm{SUP}_{\mathrm{TRANSL}}$ for expressing suitability, in which the distinction is clearly made.

On the other hand, the Finnish corpora do not contain the construction variant of the type sügis on kiire tulema ('autumn is coming quickly'), with an inanimate subject, expressing the likeliness with which something happens or the manner in which things are experienced to happen (such as in aastad on kärmed kuluma 'years go by quickly'), rather than the ability or inclination of a human or animate subject. The use of the construction with a human subject to specify its relation to some activity could be seen, at least in Finnish, as a good candidate for a prototype. In

19 The sentence is of course syntactically different from all other examples, as it is a possessive construction in which hyvä pää 'good head' is the ability being possessed, not attributed to a nominative subject. 
Estonian the use of the construction with an inanimate subject is quite common (see also examples 13 and 14).

In both languages we have also seen sentences with a clear modal aspect (someone is able, entitled, free or not free to do something). These could be seen as distinct from those examples in which it is the characteristics of the subject (hän on nopea oppimaan 's/he is quick to learn'), or even his or her own choice to some degree (Heldur polnud kitsi selleks raha kulutama 'Heldur was not mean to spend money on it'), that decides the relation to the activity marked by the supine or the MA-infinitive in the illative.

\section{The adjectival component of the schema}

With the help of corpora data we have tried to provide some description of the constructional schema [[ADJ/...][VERB-ma $\left.\left.\mathrm{INF}_{\mathrm{ILL}} / \ldots \mathrm{mAAn}\right]\right]$ in Finnish and $\left[[\mathrm{ADJ} / \ldots]\left[\mathrm{VERB}^{-S_{U P I N E}} \mathrm{ILL} / \ldots \mathrm{ma}\right]\right]$ in Estonian, concentrating on its adjectival component $[\mathrm{ADJ} / . .$.$] . This approach is not exhaus-$ tive, as other components of these constructional schemas of course also come into play. (For example, laiska 'lazy' can be used in slightly different contexts, as shown in examples (27) and (28), or nopea 'quick' in Finnish seems to be often used to express a subject's aptness, e.g. hän on nopea oppimaan 'he/she is quick to learn', whereas in Estonian kiire 'quick' typically occurred with an inanimate subject and expressed that something is perceived to happen quickly, e.g. sügis on kiire tulema 'autumn comes quickly.) While this focus does not provide a full analysis of the constructional schema, a consideration of the adjectival component reveals some features of these constructional schemas and also allows some remarks to be made on differences between Finnish and Estonian.

In some respects, the adjectival components of the Finnish and Estonian schema showed strong resemblances to each other. In both languages we have found adjectives that express 1) the subject's willingness (in Finnish valmis 'ready', halukas 'willing', haluton 'reluctant', innokas 'enthusiastic', kärkäs 'anxious', laiska 'lazy'; in Estonian agar 'ardent, 
enthusiastic', äge 'fierce, vehement', laisk 'lazy', tõrges 'wayward'), 2) the subject's suitability or ability, often decided to some degree by external conditions more than by the subject's own decision, e.g. in modal use or in a legal context (in Finnish velvollinen 'obligated', esteellinen 'disqualified, jä̈̈vi 'disqualified, challengeable', riittävä 'sufficient'; in Estonian võimeline 'capable, able', suuteline 'capable, able', võimetu 'incapable, unable', vaba 'free', kohane 'proper', kõlblik 'suitable, fit for', sobiv 'suitable'), 3) the subject's ability or inability, where we frequently encounter (in)ability in terms of promptness (in Finnish nopea 'swift', hidas 'slow', kiireinen 'hasty'; in Estonian varmas 'prompt, firm', kärme 'brisk', väle 'agile, brisk', nobe 'quick', kiire 'quick, swift', aeglane 'slow'), but also (in) ability in a more general sense (in Finnish hyvä 'good', kova 'keen', etevä 'excellent', taitava 'skilled', kykenevä 'able', kyvykäs 'capable, apt', kyvytön 'inept'; in Estonian võimeline 'capable, able', suuteline 'capable, able', pädev 'competent', sobiv 'suitable', kange 'good at, strong', küps 'ripe', visa 'persistent', ...) or affected by some other specific characteristics (in Finnish utelias 'curious', arka 'shy, timid', ujo 'shy'; in Estonian usin 'diligent', lahke 'kind, benevolent', helde 'generous', kaval 'cunning'). These are not meant as clear-cut categories, as some adjectives can very well belong to more than one of the aforementioned groups and various readings can be forwarded depending on the context in which an adjective is used.

We find the adjectives raske 'hard, heavy, difficult' and kerge 'easy, light' only in Estonian; these do not have a counterpart in Finnish. This is due to the fact that they are used only in the type of construction with an inanimate subject, expressing the likelihood with which something happens or the manner in which things are experienced to happen. On the other hand, it is only in Finnish that we encountered adjectives that have nothing to do with suitability, ability or inclination - or rather, adjectives for which this aspect is not central to their meaning (korkea 'high', nuori 'young', vanha 'old', sairas 'ill'). In these cases, the meaning of suitability is forwarded in the construction with the MA-infinitive in the illative and a modifier such as liian 'too', tarpeeksi 'enough' or kyllin 
'enough'. This type of construction is not found in Estonian, as the translative form of the supine would be used in this context.

There is also an apparent pattern in both languages: the adjective can express ability or inability, inclination or disinclination, suitability or unsuitability, i.e. the relation to the activity expressed by the MA-infinitive or supine can be expressed in both positive and negative terms. There are some clear pairs of antonyms in both languages (in Finnish for example halukas 'willing' vs. haluton 'reluctant', hyvä 'good' vs. huono 'bad, poor', kyvykäs 'capable, apt' / kykenevä 'able' vs. kyvytön 'inept', nopea 'swift' vs. hidas 'slow', vapaa 'free' vs. esteellinen 'disqualified'; in Estonian võmeline 'capable, able' vs. võimetu 'incapable, unable', kerge 'easy, light' vs. raske 'hard, heavy, difficult', kiire 'quick, swift' / kärme 'brisk' / nobe 'quick' / väle 'quick' vs. aeglane 'slow', varmas 'prompt, firm' vs. laisk 'lazy'). If the adjectives taking part in the construction are thought of as members of a category (where schema $[\mathrm{ADJ} / \ldots$... unites them, abstracting away from their specific features), the inner structure of this category would reveal a metaphoric extension via antonymy as described by Laura Janda (2003: $20-21^{20}$ ). Metaphoric extension via synonymy can of course also be considered, considering groups such as vaba 'free' - prii 'free' or väle 'quick' - nobe 'quick' - kiire 'quick, swift' - kärme 'brisk' in Estonian, and kärkäs 'anxious' - innokas 'enthusiastic' - hanakka 'eager' or esteellinen 'disqualified' - jäävi 'disqualified, challengeable' in Finnish.

Adjectives expressing a positive attitude to an activity were in general more frequent in our material than those expressing a negative attitude. In Finnish, judging from the frequency of adjectives used in the construction, valmis 'ready' or adjectives expressing subject's willingness to do an activity (valmis 'ready', halukas 'willing') can be considered a prototypical use. In Estonian, the most common case seemed to

20 In Janda's analysis the central use of the dative in Czech can be seen as that with the verb dát 'to give' (something to someone). This is extended via relationships of synonymy to other verbs that indicate the bestowal of possessions (i.e. send, lend, buy, ...), and via relationships of antonymy to use of dative with verbs that indicate the removal of possessions (for example take, steal, deny, ...). 
be adjectives denoting the subject's ability and possible participation in the activity given the circumstances (võimeline 'capable, able', suuteline 'capable, able'). In Estonian the most frequent negative adjective was võimetu 'unable, incapable', and in Finnish haluton 'reluctant, unwilling'. But in both languages, the adjectives that relate attitude in positive terms are more common. It should also be noted that, as we have seen, the genre of the texts in the corpora has some influence on the frequency of adjectives, and that another corpus might provide us with slightly different results. Nevertheless, the patterns that speak of extension through the relationships of synonymy and antonymy are clearly represented in both languages.

In the framework of cognitive grammar it is thus possible to think of the constructional schemas of both languages in terms of abstract schemas (i.e. $[\mathrm{ADJ} / \ldots]\left[\mathrm{VERB}^{-M A I N F} \mathrm{ILL}_{\mathrm{IL}} / \ldots\right.$ mAAn], [ADJ/...][VERB-SUP $\mathrm{VLL}_{\mathrm{ILL}} / \ldots$ ma]), but at the same time also consider the category of expressions that instantiate these abstract schemas in terms of the inner motivation of the category (formed by a prototypical use and its expansion through the relationships of synonymy and antonymy, for example). Also, further possible uses that would in some respect go beyond the use attested here can be expected and could be readily described.

Further research on the adjective and illative MA-infinitive/supine construction might consider the role of other components of the schema in more detail. The role of the illative morpheme in the schema and its relation to other uses of the illative is an intriguing question. Possible syntactic variations of the schema, such as those with the essive or the translative in Estonian, and the essive, translative or ablative case in Finnish, would also be worth further investigation. It would be also possible to approach the topic along different lines and, for example, compare the constructions with an adjective and the MA-infinitive/supine in the illative that can be seen as expressions of modality with other modal expressions. In this paper, the objective was to consider the constructional schema and thus to concentrate on constructions that have similar semantic and formal properties. The notion of constructional schema 
also served as a basis on which the grammar of two languages can be compared.

\section{Acknowledgements}

I would like to thank both reviewers of this article for their suggestions, Christina Saarinen for her revision of the text and suggestions about formulations, and Jeremy Bradley for his help with translating some of the Estonian example sentences into English. All errors that remain are my own.

\section{Abbreviations}

$\begin{array}{llll}\text { ABL } & \text { ablative case } & \text { MA-INF } & \text { MA-infinitive } \\ \text { ADE } & \text { adessive case } & \text { NEG } & \text { negative } \\ \text { ADJ } & \text { adjective } & \text { NOM } & \text { nominative } \\ \text { ALL } & \text { allative case } & \text { PASS } & \text { passive voice } \\ \text { CNG } & \text { connegative } & \text { PL } & \text { plural } \\ \text { COMP } & \text { comparative } & \text { POS } & \text { possessive suffix } \\ \text { COND } & \text { conditional } & \text { PST } & \text { past tense } \\ \text { ELA } & \text { elative case } & \text { PTCP } & \text { participle } \\ \text { EMP } & \text { emphatic } & \text { PTV } & \text { partitive case } \\ \text { ESS } & \text { essive case } & \text { SG } & \text { singular } \\ \text { GEN } & \text { genitive case } & \text { SUP } & \text { supine } \\ \text { ILL } & \text { illative case } & \text { TRANSL } & \text { translative case } \\ \text { INE } & \text { inessive case } & & \\ \text { IPS } & \text { impersonal voice } & & \end{array}$

\section{References}

EKG 1993 = Erelt, Mati, Reet Kasik, Helle Metslang, Henno Rajandi, Kristiina Ross, Henn Saari, Kaja Tael, Silvi Vare 1993. Eesti keele grammatika II. Süntaks. Tallinn: Eesti Teaduste Akadeemia - Eesti Keele Instituut. http:// dspace.ut.ee/handle/10062/29437

EKG 1995 = Erelt, Mati, Reet Kasik, Helle Metslang, Henno Rajandi, Kristiina Ross, Henn Saari, Kaja Tael, Silvi Vare 1995. Eesti keele grammatika I. Morfoloogia, sõnamoodustus. Tallinn: Eesti Teaduste Akadeemia - Eesti Keele Instituut. http://dspace.ut.ee/handle/10062/29448 
ISK 2004 = Hakulinen, Auli, Maria Vilkuna, Riitta Korhonen, Vesa Koivisto, Tarja Riitta Heinonen, Irja Alho 2004. Iso suomen kielioppi. Helsinki: SKS. http://scripta.kotus.fi/visk/etusivu.php

Janda, Laura A. 1993 (reprint 2013). A Geography of Case Semantics: the Czech Dative and the Russian Instrumental. Berlin-New York: Mouton de Gruyter. http://dx.doi.org/10.1515/9783110867930

Langacker, Ronald W. 1987. Foundations of Cognitive Grammar I. Theoretical Prerequisites. Stanford: Stanford University Press.

Langacker, Ronald W. 1995: Raising and transparency. - Language 71 (1), 1-62. http://dx.doi.org/10.2307/415962

Langacker, Ronald W. 2000. A Dynamic Usage-Based Model. - Michael Barlow, Suzanne Kemmer (Eds.). Usage-Based Models of Language. Stanford: CSLI Publications, 1-63.

Langacker, Ronald W. 2008. Cognitive Grammar: A Basic Introduction. Oxford: Oxford University Press. http://dx.doi.org/10.1093/acprof: oso/9780195331967.001.0001

Leino, Jaakko 2003. Antaa sen muuttua. Suomen kielen permissiivirakenne ja sen kehitys. Helsinki: SKS.

Leino, Pentti 1999. Polysemia - kielen moniselitteisyys. Kieli 7. Helsinki: Helsingin yliopiston suomen kielen laitos.

Pajusalu, Renate, Heili Orav 2008. Supiinid koha väljendajana: liikumissündmuse keelendamise asümmeetriast. - M. Erelt (Ed.), Emakeele seltsi aastaraamat 53. Tallinn: Teaduste Akadeemia Kirjastus, 104-120.

Tamm, Anne 2011. Cross-categorial spatial case in the Finnic nonfinite system: Focus on the absentive TAM semantics and pragmatics of the Estonian inessive m-formative nonfinites 1. - Linguistics 49 (4), 835-944. http:// dx.doi.org/10.1515/ling.2011.025

Tauli, Valter 1983. Standard Estonian Grammar. Part II Syntax. Studia Uralica et Altaica Upsaliensia 14. Uppsala: Acta Universitatis Upsaliensis.

Viitso, Tiit-Rein, Mati Erelt 2007. Structure of the Estonian Language. - M. Erelt (Ed.), Estonian Language. Tallinn: Estonian Academy Publishers, 9-92.

\section{Corpora}

The Balanced Corpus of Estonian / Tasakaalus korpus, www.keeleveeb.ee Kielipankki, https://sui.csc.fi

InterCorp. http://www.korpus.cz. Fárová, L.; Vavřín, M. 2015. Korpus InterCorp finština, verze 8 z 4. 6. 2015. Praha: Ústav Českého národního korpusu FF UK. 


\title{
MA-infinitiivin illatiivimuotojen yhteydessä esiintyvät adjektiivit suomessa ja virossa
}

\author{
PETRA HEBEDOVÁ \\ Masaryk yliopisto
}

Tässä artikkelissa kiinnostuksen kohteena on suomen ja viron rakenne, jossa adjektiivi esiintyy MA-infinitiivin/supiinin illatiivimuodon yhteydessä, kuten esim. olemme hitaita oppimaan / olen küps seda aktsepteerima. Rakennetta on tarkasteltu Langackerin mukaan (Langacker 2000, 2008) konstruktionaalisena skeemana, jossa adjektiivilla ilmaistu ominaisuus on suhteutettu MA-infinitiivilla/supiinilla ilmaistuun toimintaan. Huomion keskipisteessä on tämän skeeman adjektiivikomponentti (skemaattisesti [ADJ/...]). Korpustietojen avulla pyritään saamaan selville, millaiset adjektiivit yleensä esiintyvät mainitussa konstruktiossa molemmissa kielissä; viron osalta on käytetty Tasakaalus-korpusta (The Balanced Corpus of Estonian), suomen osalta rakennetta etsittiin Kielipankin lehtiteksteistä sekä monikielisestä rinnakkaisesta korpuksesta InterCorp. Tavoitteena on saatujen tietojen avulla luonnehtia skeeman adjektiivikomponenttia molemmissa kielissä ja vertailla skeeman tavanomaista käyttöä suomessa ja virossa. Korpustietojen pohjalta väitetään, että sekä suomessa että virossa voi adjektiivi ilmaista niin positiivista kuin negatiivista suhdetta MA-infinitiivilla/supiinilla ilmaistuun toimintaan (vrt. esim. suomessa halukas - haluton, nopea - hidas, virossa võimeline - võimetu, kerge - raske). Tämä tulkitaan metaforisena laajentumana antonymian kautta (Janda 2003: 20-21). Eroihin taas kuuluu se, että suomessa tätä rakennetta käytetään laajemmin sopivuuden ilmaisemiseen, jolloin adjektiivi saa usein määritteen, kuten liian, tarpeeksi, kyllin, riittävän yms. (esim. hän on liian nuori äänestämään). Virossa tällaisissa tapauksissa käytetään supiinin translatiivimuotoa (esim. ta on hääletamaks liiga noor). Virossa taas rakenne esiintyy usein myös ei-inhimillisten subjektien kanssa (vrt. esim. aastad on kärmed kuluma, jama on kerge juhtuma), erityisesti adjektiivien kerge, raske, kiire ja visa kanssa, ja tällaiselle käytölle ei ole suomessa vastinetta. Molemmissa kielissä voi adjektiivin paikalla olla substantiivilauseke (esim. hän on sopiva henkilö johtamaan yritystä ja mina 
olen õige mees talle sellest rääkima). Virossa voivat adjektiivin paikalla olla myös adverbit valmis ja nõus. Substantiivilausekkeesta ja adverbista koostuvia rakenteita käsitellään adjektiivimaisen skeeman laajennuksina - adjektiivimaisen skeeman osittain sanktioituina variantteina.

Avainsanat: illatiivi, MA-infinitiivi, supiini, kognitiivinen kielioppi, rakenneskeema, adjektiivi, antonymia

\section{Petra Hebedová}

Masaryk University, Department of Linguistics and Baltic Languages, J/J123

Arna Nováka 1/1, 60200 Brno, Czech

petrahebedova@phil.muni.cz 